\title{
TIE1 wt Allele
}

National Cancer Institute

\section{Source}

National Cancer Institute. TIE1 wt Allele. NCI Thesaurus. Code C52224.

Human TIE1 wild-type allele is located within 1p34-p33 and is approximately $22 \mathrm{~kb}$ in length. This allele, which encodes tyrosine-protein kinase receptor Tie-1 protein, plays a role in the mediation of protein-protein interactions and angiogenesis. 